\title{
Exogenic poisoning in children assisted in a pediatric emergency unit*
}

\author{
Intoxicações exógenas em crianças atendidas em uma unidade de emergência pediátrica
}

Intoxicaciones exógenas en niños atendidos en una unidad de emergencia pediátrica

\author{
Juliana Lourenço ${ }^{1}$, Betise Mery Alencar Furtado ${ }^{2}$, Cristine Bonfim ${ }^{3}$
}

\begin{abstract}
Objective: To describe the epidemiological characteristics of all exogenic poisoning cases in children assisted in a pediatric emergency unit in Recife, State of Pernambuco, Brazil, from April to September 2006. Methods: This is a descriptive study of exogenic poisoning in 0-12 aged children treated at Centro de Assistência Toxicológica de Pernambuco (Pernambuco Toxicological Assistance Center). The data were collected through interviews and by consulting patients' records. Results: 26 cases of accidental exogenic poisoning were registered, mainly males (65.4\%). Regarding age, children under five years old were the most affected (65.4\%). Medication was involved in $50.0 \%$ of the cases. Conclusion: Accidental exogenic poisoning affecting children younger than five years of age stands out as a significant public health problem. As a member of a multiprofessional health team, the nurse plays an important role in health education and in the measures to prevent child poisoning.
\end{abstract}

Keywords: Poisoning/epidemiology; Toxic substances; Child; Accidents, home; Accident prevention

\section{RESUMO}

Objetivo: Descrever as características epidemiológicas dos casos de intoxicações exógenas em crianças atendidas em uma unidade de emergência pediátrica do Recife (PE), no período de abril a setembro de 2006. Métodos: Estudo descritivo dos casos de intoxicações exógenas ocorridos em crianças na faixa etária de 0 a 12 anos de idade notificados no Centro de Assistência Toxicológica de Pernambuco. Os dados foram coletados através de entrevistas e consultas às fichas de atendimento hospitalar.Resultados: Foram registrados 26 casos de intoxicação exógena acidental. Predominou o sexo masculino $(65,4 \%)$ e a faixa etária dos menores de cinco anos de idade foi a mais acometida (65,4\%). Os medicamentos estavam envolvidos em 50,0\% dos casos. Conclusão: A intoxicação exógena acidental de crianças, sobretudo em menores de cinco anos é um problema de saúde pública que requer medidas preventivas para evitar sua ocorrência na infância. Descritores: Envenenamento/epidemiologia; Substâncias tóxicas; Criança; Acidentes domésticos; Prevenção de acidentes

\section{RESUMEN}

Objetivo: Describir las características epidemiológicas de los casos de intoxicaciones exógenas en niños atendidos en una unidad de emergencia pediátrica de Recife (PE), en el período de abril a setiembre del 2006. Métodos: Se trata de un estudio descriptivo de los casos de intoxicaciones exógenas ocurridos en niños del grupo etáreo de 0 a 12 años de edad notificados en el Centro de Asistencia Toxicológica de Pernambuco. Los datos fueron recolectados a través de entrevistas y consultas a las fichas de atención hospitalaria.Resultados: Fueron registrados 26 casos de intoxicación exógena accidental. Predominó el sexo masculino $(65,4 \%)$ siendo el grupo etáreo de menores de cinco años de edad el más afectado (65,4\%). Los medicamentos estaban involucrados en el 50,0\% de los casos. Conclusión: La intoxicación exógena accidental de niños, sobre todo en menores de cinco años es un problema de salud pública que requiere medidas preventivas para evitar que ocurra en la infancia.

Descriptores: Envenenamiento/epidemiología; Sustancias tóxicas; Niño; Accidentes domésticos; Prevención de accidentes

\footnotetext{
* Work carried out at Hospital da Restauração of the Pernambuco State Health Secretariat, Recife, (PE), Brazil.

${ }^{1}$ Nursing Intern at Hospital da Restauração of the Pernambuco State Health Secretariat, Recife, (PE), Brazil.

${ }^{2}$ Master's degree in Public Health; Professor at the Escola de Enfermagem Nossa Senhora das Graças at Universidade de Pernambuco-UPE - Recife, (PE), Brazil.

${ }^{3}$ Master's degree in Public Health; Researcher at Fundação Joaquim Nabuco. Recife, (PE), Brazil.
} 


\section{INTRODUCTION}

Accidents in childhood are a public health serious problem in the world. In the developed countries, accidents are the major mortality cause in children over a year old. They contribute significantly to morbidity in childhood ${ }^{(1-2)}$. Furthermore, the nonfatal accidents represent an important cost for the health systems ${ }^{(3-4)}$. Estimates show that one in four children is severely injured so as to require medical care $^{(3)}$.

In Brazil, in 2005, death-related accidents in the under a year old group age occupied sixth place in the mortality ranking in this group age. Among the external mortality factors, the transport accidents constitute the main ones, with falls coming next. In this year, except for perinatal disorders and congenital malformations, the external factors were the main mortality cause in the group age of $0-14$ years. The exogenic poisoning represented $0.06 \%$ of mortality rates in this group $\operatorname{age}^{(5)}$

The exogenic poisoning is one of the main children affecting accidents and are responsible for approximately $7 \%$ of all accidents with children under five and are involved in around $2 \%$ of all children deaths in the world $^{(6)}$

Usually, the exogenic poisoning in this group age is accidental and preventable. They are consequence of facilitating situations, of characteristics typical of the children development phases and the meager investment in preventive measures ${ }^{(7-12)}$.

According to data of the National System of Pharmacologic-Toxic Information of the Oswaldo Cruz Foundation, in Brazil, in 2005, 84.356 cases of human poisoning were reported. The group age of zero to five years old was the most affected, with $17.238(22.3 \%)$ cases and 30 deaths. Among the main toxic agents, causing poisoning in children in this group age, are the medications (35\%), cleaning products $(18 \%)$ and the industrial chemical products $(9 \%)^{(13)}$.

The identification and description of the epidemiological characteristics of exogenic poisoning in childhood are significantly relevant for the treatment and prevention measure planning. In this perspective, this work aimed at studying the exogenic poisoning cases occurred with 0-12 year old children treated in a pediatric emergency unit at the Restoration Hospital and reported by the Pernambuco Toxicological Assistance Center (CEATOX), in the April to September, 2006 period.

\section{METHODS}

This is an epidemiological descriptive prospective study performed in the pediatric emergency room of the Restoration Hospital, localized in the city of Recife, $\mathrm{PE}$, which is state public reference for patients of trauma, poisoning and neurological conditions. Case has been defined as any child in the group age of zero to 12 years old treated in a pediatric emergency unit, due to exogenic poisoning, and reported by the Pernambuco Toxicological Assistance Center, in April to September, 2006 period.

The children were inserted in the study on the condition that their parents or tutors authorized and signed the consent form. There was not parents or tutors' denial in participating in the study. The research project was approved by the Committee of Ethics in Research of the Restoration Hospital.

Data were collected from the hospital records (gender, age, toxic agent, exposure and evolution via) and from interviews with parents or tutors of the children. There was a structured questionnaire, composed of closed questions about the accident (place and time of poisoning occurrence, presence of adults in the accident moment)

The software EpiInfo version 6.04d. was used to process the data. With the databank structured, there were analyses of Analysis and Epitable modules.

\section{RESULTS}

In the study period, 26 children under 13 were admitted in the pediatric emergency unit of Restoration Hospital (RH) due to accidental exogenic poisoning, being $0.29 \%$ of the overall 9000 treatments in the pediatric emergency room. Data in Table 1 show that of the 26 children, $17(65.4 \%)$ were males and $9(34.6 \%)$ were females The case distribution in function of group age showed that $64.5 \%$ of the children were under five. However, there was not any case in children under one. Medication ingestion was present in $50 \%$ of the cases. The anticonvulsive medications and bronchodilators had the highest number of cases, three, respectively. In all the poisoning cases, the exposure via was oral. Over $80 \%$ of the accidents occurred indoors, and the kitchen was the room with the most occurrences. The most frequent part of day with poisoning occurrences was the evening $(42.3 \%)$, followed by the night (38.5\%). Regarding the presence of people looking after the children in the accident moment, the parents were present in 15 cases $(57.7 \%)$. In only one case, care in the Intensive Care Unit (ITU) was necessary. It was a three-year old male child who took nitric acid medicine and eventually died. 
Table 1-Children admitted in the pediatric emergency room of the Restoration Hospital, according to the studied variables - April to September, 2006.

\begin{tabular}{|c|c|c|}
\hline Variables & $\mathbf{n}$ & $\%$ \\
\hline \multicolumn{3}{|l|}{ Group age } \\
\hline$<5$ years & 17 & 65.4 \\
\hline $5-10$ years & 8 & 30.8 \\
\hline $10-12$ years & 1 & 3.8 \\
\hline \multicolumn{3}{|l|}{ Gender } \\
\hline Male & 17 & 65.4 \\
\hline Female & 9 & 34.6 \\
\hline \multicolumn{3}{|l|}{ Type of poisoning } \\
\hline Medication & 13 & 50.0 \\
\hline Pesticides and Insecticides & 6 & 23.1 \\
\hline Cleaning Products & 6 & 23.1 \\
\hline Others & 1 & 3.8 \\
\hline \multicolumn{3}{|l|}{ Exposure Via } \\
\hline Oral & 26 & 100.0 \\
\hline \multicolumn{3}{|l|}{ Occurrence Place } \\
\hline Bedroom & 7 & 26.9 \\
\hline Kitchen & 8 & 30.8 \\
\hline Living room & 6 & 23.1 \\
\hline Outdoors & 3 & 11.5 \\
\hline Others & 2 & 7.7 \\
\hline \multicolumn{3}{|l|}{ Occurrence Part of Day } \\
\hline Morning & 5 & 19.2 \\
\hline Evening & 11 & 42.3 \\
\hline Night & 10 & 38.5 \\
\hline \multicolumn{3}{|c|}{ Adults in the occurrence moment } \\
\hline Parents & 15 & 57.7 \\
\hline Siblings & 2 & 7.7 \\
\hline Grandparents & 3 & 11.5 \\
\hline Uncles/Aunts & 2 & 7.7 \\
\hline Cousins & 2 & 7.7 \\
\hline Others & 2 & 7.7 \\
\hline \multicolumn{3}{|l|}{ Hospital Admission } \\
\hline Emergency room & 25 & 96.2 \\
\hline ITU & 1 & 3.8 \\
\hline \multicolumn{3}{|l|}{ Evolution } \\
\hline Cure & 25 & 96.2 \\
\hline Death & 1 & 3.8 \\
\hline
\end{tabular}

\section{DISCUSSION}

The exogenic poisoning represents one of the most common medical emergencies in the group age of zero to 12 years old and constitute a relevant problem in public health ${ }^{(7,8,14-17)}$. The findings demonstrate that within six months, $0.29 \%$ of the overall treatments in the $\mathrm{RH}$ pediatric emergency room were due to exogenic poisoning in children under 13. In Spain, a research on children poisoning carried out in 17 pediatric emergency rooms, for two years, identified that $0.28 \%$ of all admissions were due to poisoning ${ }^{(7)}$.

Despite the fact that this work is restricted to hospital admissions and there are an expressive number of unreported poisoning cases in the country ${ }^{(9,18)}$, researches carried out in other countries and in Brazil have demonstrated the study potentialities of the epidemiological characteristics of exogenic poisoning cases in the hospital setting which allow to estimate the incidence rates, the main factors and substances involved with poisoning in childhood, the most vulnerable group age. An analysis of the elements associated with symptomatic and asymptomatic cases enables an examination of the preventive strategies and educative $\operatorname{programs}^{(7,16-23)}$.

The findings confirm the pattern shown in other papers: greater poisoning incidence in children under five, predominance of males, most accidents indoors and presence of parents when the accidents occurred ${ }^{(7,16-23)}$.

Children, especially those under five, are prone to be exposed to exogenic poisoning given that they are curious and are developing their motor skills ${ }^{(12,24-25)}$. From zero to six months old, the newly born communicates with the world through its crying. In this period, the poisoning is caused by medicine administration or other substances given by parents and/ or tutors ${ }^{(24)}$.

In the group age of one to four years old, as children are growing and developing, they are capable of walking and showing their nimbleness. They are capable of reaching objects, handling them, taking them to their mouths and in these discovery and entertainment moments the accidents happen ${ }^{(24)}$.

Also, in this group age, children become skilled. They can open most containers and packages and their skills allow them to have access to places where families usually leave medicine and other objects that pose threats ${ }^{(24-27)}$. Furthermore, as children grow, people watching them tend to underestimate their capacities and leave dangerous substances within reach ${ }^{(8,24,26)}$.

The exogenic poisoning occurrences in the group age of zero to ten years old decrease. However, in this group age, other types of accident tend to occur: as children grow and move further, they become more independent and expose themselves more frequently to environmental risks ${ }^{(19)}$.

Medicines were the most common agent involved in the exogenic poisoning $(50.0 \%)$, followed by cleaning products $(23.1 \%)$, insecticides and pesticides $(23.1 \%)$, and the exposure via was oral. Of the 13 poisoning cases that involved medicines, there was predominance of anticonvulsives and bronchodilators. According to what was verified in other studies, the pharmaceutical substances have been the most frequent non-intentional poisoning category in childhood, especially in the group age of children under five $\mathrm{e}^{(7-11,16-23)}$.

Specifically in Brazil, $33 \%$ of the medicine poisoning cases were reported to the National Network of Poisoning Control Centers were of children under five ${ }^{(28)}$.

A study on the medicine poisoning in children under five, in Brazil, found the five medicine groups with the 
highest number of cases: nasal decongestants, painkillers, bronchodilators, anticonvulsives and oral contraceptives $^{(18)}$.

The causes of medicine ingestion by children may include aspects related to attractive packaging, pleasant taste content and above all, the absence of children protective special packaging. Also, consideration should be given for medicine toxicity, self medication practice and failure in storing and administering medication ${ }^{(11,18,26-29)}$.

In general, the exogenic poisoning results in important morbidity (high incidence), low lethality and short hospitalization $^{(7,10,16-23)}$. This study showed that of the 26 poisoning cases admitted in the emergency room, only one required ITU care. The others required simple procedures. Only one death was registered during the study period; Indeed, the poisoning lesions, and increased incidence, the treatment costs and the likelihood of irreversible sequels, play a key role in the accident category in childhood.

Preventive measures have been remarkably successful in reducing the frequency and severity of children poisoning. The adoption of safety packaging in medicine and chemical products is a measure that has reduced the poisoning incidence $^{(27,30-32)}$. In the United States of America, after using the children protective special packaging, the accidental ingestion of substances declined roughly $40 \%$ between 1973 and 1978. The mortality rates of exogenic poisoning in children declined from 2.0/100.000 children to 0.5 / 100.000, between 1973 and $1982^{(30)}$.

Another aspect refers to the medicine consumption pattern in Brazil, characterized by a lack of control, both in production as in commerce. One of the main consequences of this pattern is the increase in poisoning caused by toxic agents. An educative campaign regarding medicine use care, associated with sales and medical prescription, would contribute to reducing poisoning cases in childhood ${ }^{(18,28)}$.

The information and toxicological assistance centers also play an important role in reducing morbidity and mortality, with trained professionals available 24 hours a day so as to inform about home decontamination procedures. They would reduce the emergency service

\section{REFERENCES}

1. Peden M, McGee K, Sharma G. The injury chart book: a graphical overview of the global burden of injuries. Geneva: World Health Organization; 2002.

2. Pan SY, Ugnat AM, Semenciw R, Desmeules M, Mao Y, MacLeod M. Trends in childhood injury mortality in Canada, 1979-2002. Inj Prev. 2006; 12(3):155-60.

3. Philippakis A, Hemenway D, Alexe DM, Dessypris N, Spyridopoulos T, Petridou E. A quantification of preventable unintentional childhood injury mortality in the United States. Inj Prev. 2004; 10(2):79-82.

4. Danseco ER, Miller TR, Spicer RS. Incidence and costs of admissions, as medical-hospital care can be used when it is indeed necessary, also contributing to reducing the expenditure of public health systems $\mathrm{s}^{(12,21,27)}$.

Information of products that cause morbidity and mortality is an important element to lead health education actions. In Porto Alegre, RS, one of the adopted actions consists of the distribution of educative leaflets about accident prevention in the household. Also, the "state day to prevent toxic accidents" was instituted and the health organizations discuss poisoning prevention measures $^{(21)}$.

An important contribution can be given by the "Family Health Strategy" in order to reduce poisoning in childhood. This health care model aims at promoting family health, considering both physical and social setting. The intervention of the professional nurse in the socioeconomic and cultural setting of the families allows to plan preventive actions closer to the community reality. The health community agents, during their visits, will be able to inform about medicine storage care and chemical products used at home, also providing guidance to parents regarding home care when there is poisoning.

The nursing professionals perform relevant tasks, both preventing and treating poisoning in childhood: they prevent, subsiding the implementation of school, day care and community programs and basic health care; they treat, performing a nursing assistance plan for the poisoned children and providing guidance to the parents and/or tutors regarding poisoning home care.

\section{CONCLUSION}

One of the limitations of this study was the low number of exogenic poisoning cases reported; despite this limitation, the findings suggest that the accidental poisoning of children, especially in the group age under five, consists of a relevant public health problem, deserving a widespread public campaign to prevent poisoning in childhood. The nurse, as constituent of the multiprofessional health care team, performs an important role in health education and poisoning prevention measures in childhood.

1987-1994 childhood injuries: demographic breakdowns. Pediatrics. 2000; 105(2):E27.

5. Ministério da Saúde. DATASUS [Internet]. Brasília(DF): Ministério da Saúde; c2003. [citado 2008 Jan 10]. Disponível em: http://www.datasus.gov.br.

6. Jepsen F, Ryan M. Poisoning in children. Curr Paediatr. 2005; 15(7): 563-8.

7. Mintegi S, Fernández A, Alustiza J, Canduela V, Mongil I, Caubet I, et al. Emergency visits for childhood poisoning: a 2 -year prospective multicenter survey in Spain. Pediatr Emerg Care. 2006; 22(5):334-8. 
8. Martin TC, Brinkman W. The spectrum of accidental childhood poisoning in the Caribbean. Rev Panam Salud Publica. 2002; 12(5):313-6.

9. Bucaretchi F, Baracat ECE. Exposições tóxicas agudas em crianças: um panorama. J Pediatr (Rio J). 2005; 81(5 Supl):S212-S22.

10. Wilkerson R, Northington L, Fisher W. Ingestion of toxic substances by infants and children: what we don't know can hurt. Crit Care Nurse. 2005; 25(4): 35-44.

11. Chien C, Marriott JL, Ashby K, Ozanne-Smith J. Unintentional ingestion of over the counter medications in children less than 5 years old. J Paediatr Child Health. 2003; 39(4):264-9.

12. Shannon M. Ingestion of toxic substances by children. $N$ Engl J Med. 2000; 342(3):186-91.

13. Ministério da Saúde. Fundação Oswaldo Cruz. Sistema Nacional de Informações Tóxico-Farmacológicas-SINITOX. Centro de Informação Científica e Tecnológica [Internet].Casos registrados de intoxicação humana e envenenamento. Brasil, 2005. [citado 2007 Set 13]. Disponível em: http://www.fiocruz.br/sinitox/

14. Litovitz T, White NC, Watson WA. Epidemiology of Pediatric Poison Exposures: An Analysis of 2003 Poison Control Center Data. Clin Ped Emerg Med. 2005; 6:68-75.

15. Abbruzzi G, Stork CM. Pediatric toxicologic concerns. Emerg Med Clin North Am. 2002; 20(1): 223-47.

16. Lam LT. Childhood and adolescence poisoning in NSW, Australia: an analysis of age, sex, geographic, and poison types. Inj Prev. 2003; 9(4):338-42.

17. Hoy JL, Day LM, Tibballs J, Ozanne-Smith J. Unintentional poisoning hospitalisations among young children in Victoria. Inj Prev. 1999; 5(1):31-5.

18. Matos GC, Rozenfeld S, Bortoletto ME. Intoxicações medicamentosas em crianças menores de cinco anos. Rev Bras Saude Matern Infant. 2002; 2(2):167-76.

19. Amador JC, Thomson Z, Guilherme CES, Rocha SF. Perfil das intoxicações agudas exógenas infantis na cidade de Maringá (PR) e região, sugestões de como se pode enfrentar o problema. Pediatria (Sao Paulo). 2000; 22(4): 295-301.
20. Marchi AG, Renier S, Messi G, Barbone F. Childhood poisoning: a population study in Trieste, Italy, 1975-1994. J Clin Epidemiol. 1998; 51(8):687-95.

21. Ramos CLJ, Targa MBM, Stein AT. Perfil das intoxicações na infância atendidas pelo Centro de Informação Toxicológica do Rio Grande do Sul (CIT/RS). Cad Saude Publica $=$ Rep Public Health. 2005; 21(4):134-1141.

22. Martins CBG, Andrade SM, Paiva PAB. Envenenamentos acidentais entre menores de 15 anos em município da Região Sul do Brasil. Cad Saude Publica $=$ Rep Public Health. 2006; 22(2):407-14.

23. Baracat ECE, Paraschin K, Nogueira RJN, Reis MC, Fraga AMA, Sperotto G. Acidentes com crianças e sua evolução na região de Campinas, SP. J Pediatr (Rio J). 2000; 76(5):368-74.

24. Scherz RG. Prevention of childhood poisoning. A community project. Pediatr Clin North Am. 1970; 17(3):713-27.

25. Schvartsman C, Schvartsman S. Intoxicações exógenas agudas. J Pediatr (Rio J). 1999; 75(Supl.2): S244-S50.

26. Bochner R. Papel da Vigilância Sanitária na prevenção de intoxicações na infância. REVISA. Rev Bras Vigilância Sanit. 2005; 1(1): 50-7.

27. Ozanne-Smith J, Day L, Parsons B, Tibballs J, Dobbin M. Childhood poisoning: access and prevention. J Paediatr Child Health. 2001; 37(3): 262-5.

28. Bortoleto ME, Bochner R. Impacto dos medicamentos nas intoxicações humanas no Brasil. Cad Saude Publica = Rep Public Health. 1999; 15(4):859-69.

29. Soori H. Developmental risk factors for unintentional childhood poisoning. Saudi Med J. 2001; 22(3):227-30.

30. Walton WW. An evaluation of the Poison Prevention Packaging Act. Pediatrics. 1982; 69(3):363-70.

31. Rodgers GB. The safety effects of child-resistant packaging for oral prescription drugs. Two decades of experience. JAMA. 1996; 275(21): 1661-5.

32. Clarke A, Walton WW. Effect of safety packaging on aspirin ingestion by children. Pediatrics. 1979; 63(5):687-93. 